\title{
Obligations of Poor Countries in Ensuring Global Justice: The Case of Uganda
}

John Barugahare ${ }^{1}$ and Reidar K. Lie ${ }^{2}$

${ }^{1}$ University of Bergen, Department of Philosophy

John.Barugahare@fof.uib.no

${ }^{2}$ University of Bergen, Department of Philosophy

Reidar.Lie@fof.uib.no

Obligations of global justice rest mainly on the global rich but also to a lesser extent on the global poor. The governments of poor countries are obliged to fulfill requirements of nonaggression, good governance and decency, along with all other requirements which facilitate the achievement of global justice. So far, obligations of poor countries seem to be taken as given yet the behavior of governments in poor countries and occurrences therein attest to the contrary; this suggests a need to mainstream these obligations in discussions about global justice. If poor countries do not live up to these requirements obstacles arise to the realization of global justice; and they act unjustly in relation to citizens of rich countries which provide them with aid. Uganda is taken as a case in point.

Keywords: global justice, obligations, poor countries, Uganda

\section{Introduction and Background}

The existing literature on global justice reflects the dominant attention given to what the rich countries should do in order to alleviate poverty and suffering among the global poor. This discussion has proceeded at the expense of debates about potential obligations of poor countries themselves. Some of the contributors to the global justice debate such as Fiona Terry (2000), William Easterly (2006) and Paul Collier (2008), among others, have hinted at the need to explore obligations of poor countries. In their works they allude to something along the lines of, "part of the solution for poverty in poor countries lies within the poor countries themselves." However, the conclusions reached by each of them do not explicitly emphasize the obligations of poor countries in global justice. This trend risks encouraging complacency among resource-poor countries like Uganda in the implementation of global justice. In this paper, the argument is not that the contents of present works on global justice are wrong regarding obligations of rich countries; nor is it that some of these contributors would deny the importance of obligations of poor countries in ensuring global justice. Rather the argument of this paper is that the current debate focuses on what rich countries should do while this alone is unlikely to result in 
global justice. Therefore, for practical and moral reasons, in addition to the obligations of rich countries, the debate needs to mainstream reflections on possible obligations of poor countries and on what should be done if they do not fulfill these obligations. The trend of thinking beyond obligations of rich countries in ensuring global justice is not unprecedented. Recently, using South Africa as a case study Nicola Barsdorf argued that middleincome countries have moral obligations to help solve some of the problems afflicting poorer countries (2012). Drawing on this background, this paper argues for three kinds of obligations of poor countries in ensuring global justice: 1) Obligations of international justice (non-aggression); 2) The obligation of effective management of aid resources; and 3) The obligation to exercise due diligence (decency). We will begin by giving a brief survey of the ongoing discussion about obligations for global justice with the intention to show that, despite wide recognition of the importance of poor country obligations, these obligations have continuously failed to reach the same level of prominence as those of rich countries.

\section{The Ongoing Debate}

To begin with, Peter Singer in two essays: Famine, Affluence and Morality (1972) and The Singer Solution to World Poverty (1999); and in his book One World: The Ethics of Globalization (2000), is primarily concerned with justifying the moral obligations of rich countries to give aid to the global poor. Singer discusses at length what citizens and governments of affluent countries can do in order to ensure global justice. At the same time, however, he recognizes the importance of obligations of poor countries for utility reasons yet he does not pursue this subject at length.

On the other hand, in his 2008 World Poverty and Human Rights Thomas Pogge portrays global justice predominantly in terms of the negative duties of affluent countries in ensuring global justice. He argues that:

[...] we [the rich] share responsibility not only for the damage authoritarian rulers [in poor countries] can do to the interests of 'their' people, [...] our governments have instigated violent installation of many oppressive rulers in poor countries [...] and have fostered a culture of corruption [...] (2008: 29).

In Pogge's view, "it is quite possible that within a different global order national factors [in poor countries] that tend to undermine the fulfillment of human rights would occur much less often or not at all" (2005: 22). Like Singer, Pogge hints at the obligations of poor countries, in particular the duty of governments in poor countries to oppose the global institutional order that is sustained by powerful governments in the North and global organizations such as the World Trade Organization (WTO) and the International Monetary Fund (IMF). However, he does not dedicate sufficient space to this subject.

David Miller is also concerned with the issue of "what responsibilities do we have towards the global poor? What must we do for them as a matter of justice?" (2007: 231). As an allusion to the obligations of poor countries, Miller cautions that human beings 
should be treated "both as agents capable of taking responsibility for the outcomes of their actions and as vulnerable and needy creatures who may not be able to lead decent lives without the help of others" (2007: 237, italics in original text). By emphasizing their agency Miller clearly says that citizens of poor countries have the capacity to take decisions and assume responsibility for their outcomes. This is a clear indication that he believes that obligations of poor countries are an important complement to those of rich countries for the achievement of global justice. Yet Miller does not mainstream this subject in his work either.

Further, in the The problem of Global Justice, Thomas Nagel castigates the current unjust international order, which he rightly blames on the affluent countries. His argument is that "[ $t]$ he global economy, within which the familiar inequalities are now generated, requires a stable international system of property rights and contractual obligations that provide the conditions for international commerce" (2005: 137). In Nagel's view it is a duty of affluent countries to reform the rules of international trade to the benefit of poor countries.

Further suggestions regarding the need to explore obligations of poor countries in global justice can be found in the works of Terry (2000), Easterly (2006), and Collier (2008). From her experience of how aid to refugees in poor countries is mismanaged, Fiona Terry, in Condemned to Repeat? The paradox of humanitarian action, concludes that "[i]f international agencies [and all donors] are to meet the needs of the populations in crisis, their [donors] organizational behavior must adjust to the wider political and socio-economic contexts in which aid occurs." Yet, from her research findings which led her to draw this conclusion, a complementary conclusion can also be drawn: If international agencies are to meet the needs of populations in crisis in poor countries, poor countries must bear a stringent obligation not to mismanage aid resource. Hence, even though Terry does not explicitly suggest the need for poor countries to bear some obligations, her findings clearly suggest this need.

Furthermore, in The White Man's Burden, Easterly sets out to investigate "[w]hy the West's efforts to aid the rest have done so much ill and so little good," (2006: 115) and comes to the conclusion that "[i]t is all about [bad] politics" in poor countries; and this blame is shared by International Financial Institutions (IFIs), which he accuses of "coddling awful gangsters who just call themselves a government" in poor countries (Easterly 2006: 152-153). His point concerns the complicity between government bureaucrats of poor countries, multinational corporations and IFIs. The implication being that in order to break down the complicity between the representatives of rich countries and government bureaucrats of poor countries it is important that, for example, Pogge's argument for negative duties on the part of rich countries be supplemented with duties imposed on poor country governments to desist from complicity.

Further still, even though Collier's The Bottom Billion: Why are poor countries failing and what can be done about it (2008) does not deal with explicit obligations of poor countries, and these obligations are not given any direct or considerable attention, on many occasions he does allude to something along those lines, however. For example, while he believes that one of the challenges for Africa's development is bad governance which 
needs external help in the form of technical assistance, he cautions that this kind of aid can only be effective if the political conditions in the benefiting country are favorable (Collier 2008: 108-115). In other words, if any kind of aid to poor countries is to be effective, governments of poor countries have a duty to create favorable conditions for such aid.

Generally, there is a great deal of evidence that most contributors to the debate about global justice recognize, in the back of their mind, the importance of obligations of poor countries in ensuring global justice. Yet at the same time it is also evident that a discussion of these obligations is far less developed than that of the obligations of rich countries. Since, like those sampled above, most contributors imply that obligations of poor countries are also important for purposes of effectiveness and yet then fail to dedicate sufficient attention to such obligations, there is a need to bridge this gap. Accordingly, this work should be seen as supplementary to their contribution to the debate rather than as a criticism of their work.

\section{Poor Countries' Obligations Relating to International Justice}

Obligations of international justice are understood here as treaty obligations and prohibition of interventions in legitimate internal affairs of other countries. In principle they apply equally to both poor and rich countries. For this reason it may be tempting to take these obligations for granted in relation to poor countries and negate the need for special discussion. However, this would only ring true under international law. As international law is quite complex and difficult to implement, these obligations would benefit from being integrated into debates about global justice founded on diffuse pressure to secure compliance. Hence, the obligations of poor countries in international justice need to be emphasized and made more stringent than they currently are in discussion of global justice - as illustrated below using the duty of non-aggression.

The popular discussion on international justice concentrates on demonstrating and castigating the guilt of rich countries in international justice. As shown above, this has been the primary concern of key contributors to the global justice debate (Miller 2007; Nagel 2005; Pogge 2001, 2005, 2008, among others). Don Scheid has argued that "[a] great part of global justice must concern itself with the use of force, especially the aggressive use of force. In the quest for global justice and international governance, one strategy is to impose legal constraints on the use of force by outlawing acts and wars of aggression" (2003). But even for a case as clear as the prohibition of aggression, the popular debate about global (social) justice is silent when it comes to obligations of poor countries in cases of non-aggression. In this section we want to show that even though poor countries are victims of global social injustice, they are also at times perpetrators of injustice against other poor nations and states. Therefore, in the pursuit of global justice, there is a need to seriously evaluate the moral dilemma of dealing with harmful victims. ${ }^{2}$ We will use Uganda as a case to illustrate this point. 


\section{Poor Countries, Armed Aggression and Global Justice}

In considering the case of armed aggression in a paper discussing issues related to the ethics of underdevelopment, mal-development and associated injustices, it is important to concede that issues of social justice are often treated separately than those of conflict and post-conflict situations. However, a country that engages in destructive armed aggression against another deprives its victim of material livelihoods and socially afflicts its citizens, thus affecting their material and social well-being, which are key indicators on their Human Development Index (HDI). The comparison of inter-country HDI is the most important criterion in assessing the status of global justice. Hence, if the focus of debates about social justice is the analysis and assessment of the causes and solutions of global inequalities in material and social well-being, then all relevant factors that directly affect economic and social well-being ought to be accounted for and examined. One major factor in this category is armed aggression.

\section{The Uganda-Democratic Republic of Congo Case}

Between 1997 and 2003, the Ugandan army (Uganda People's Defense Forces - UPDF), invaded the Democratic Republic of the Congo (DRC), ostensibly to fight the Allied Democratic Forces (ADF) who were rebelling against the Ugandan government. However, contrary to their proclaimed justification, the army looted minerals, timber and other resources, destroyed the livelihoods of local citizens, conscripted children into the army, and committed other inhumane crimes such as rape. Other offenses also included facilitating rebel activities in the regions they invaded (International Court of Justice (ICJ) 2005).

According to the findings of the ICJ, “THE COURT," by sixteen votes to one,

Finds that the Republic of Uganda, by engaging in military activities against the Democratic Republic of the Congo on the latter's territory, by occupying Ituri and by actively extending military, logistic, economic and financial support to irregular forces having operated on the territory of the DRC, violated the principle of non-use of force in international relations and the principle of non-intervention (ICJ 2005: 280).

Further, by the same vote (16:1) it was agreed that:

The Republic of Uganda, by the conduct of its armed forces, which committed acts of killing, torture and other forms of inhumane treatment of the Congolese civilian population, destroyed villages and civilian buildings $[\ldots]$ violated its obligations under international human rights law and international humanitarian law (ICJ 2005: 280).

In addition, the International Court of Justice found that:

[...] the Republic of Uganda, by acts of looting, plundering and exploitation of Congolese natural resources committed by members of the Ugandan armed forces in the territory of the Democratic 
Republic of the Congo and by its failure to comply with its obligations as an occupying power in Ituri district to prevent acts of looting, plundering and exploitation of Congolese natural resources, violated obligations owed to the Democratic Republic of the Congo under international law (ICJ 2005: 280-281).

Uganda was found guilty of so many counts of injustice that they cannot all be listed here. Ultimately, the International Court of Justice in the vote of sixteen to one unanimously, "[f]inds that the Republic of Uganda is under obligation to make reparation to the Democratic Republic of the Congo for the injury caused; [...]" (ICJ 2005: 281). The reparation was set at $\$ 10$ billion USD; this implies that as a result of the invasion by Uganda, DRC loss of property, life, and well-being was valued at $\$ 10$ billion USD. While of course this seems to be an issue which can be addressed purely by International Law, it is important to show how incorporating this subject in discussions about global justice would be instrumental in efforts towards achieving global justice.

As mentioned above, the issue of armed aggression becomes of interest in the debate about global justice due to its direct effect on material and non-material well-being of the victims. Since this issue was left purely to the realm of international law it may have been considered a settled question, yet no justice has been achieved thus far as long as Uganda lacks the capacity, or is unwilling, to pay the reparation. However, if this had been stated in advance as a stringent obligation of social justice upon Uganda, social pressure exerted through diplomacy would very likely have, to a large extent, played a preventive role in the first place. Therefore, regarding the characterization of the specific obligations of poor countries in ensuring global justice, it can be said that since the level of material and nonmaterial well-being are key proxies for global justice, it is important that poor countries' obligation to desist from armed aggression against other nations and states should be made more stringent because such aggression directly tilts the balance of global justice against victims. Of course this obligation is borne by the rich countries too, but the point here is that since there is evidence that through the violation of this obligation some poor countries have exacerbated the material and social well-being of others, hence in the discussion of the obligations of poor countries this obligation warrants special emphasis.

The implication of the above case is that failure to fulfill obligations of international justice (for example of non-aggression) and the consequent damage leads to injustice against those who must repair the damage through relief and development aid. For example, since Uganda could not alleviate the deprivation in the DRC as it lacked the requisite resource capacity to do that, then, following David Miller's criteria for assigning remedial responsibility in global justice (2007), the natural place to look is the agent with the capacity to alleviate the harm - the governments and citizens of affluent countries. However, if the citizens of affluent countries are subjected to enforceable obligations to provide aid for alleviating harm inflicted by other countries in this way, it constitutes a clear injustice, especially if no sanctions are meted out against perpetrators for flouting their obligations. It is for this reason that when thinking about global justice, poor countries must bear the positive as well as negative obligations of international justice. If poor countries fail on these counts then they ought to suffer the sanctions attached to corresponding obligations. 
However, in dealing with harmful victims like Uganda, sanctions imposed for failure on their obligations are likely to engender moral dilemmas. It raises other issues pertaining to the relations between the citizens of poor countries and their governments. Ordinarily, when one speaks of the duties and responsibilities of poor countries, these should be duties and responsibilities of the governments and the citizens jointly. However, this would only be the case if governments of poor countries were as representative as those of the democratic and affluent countries, such that the actions and inactions of governments are influenced, and therefore owned by their citizens. This dilemma does not only arise in the implementation of international justice obligations, but also in many other instances. We will return to this and other challenges towards the conclusion.

\section{Obligation Pertaining to Aid}

In discussing strategies for global justice, obligation to aid is dominant. However, aid can be a double-edged sword for and against poor countries. Whereas aid can provide immediate relief to the global poor, it can also be abused by aid-givers to create an exploitative dependency relationship between the poor and the rich and in this way uphold global injustices. However each of these two possibilities depends on how aid is conceived. If aid is conceived as charity, it can easily be abused to uphold global injustices. But on the other hand if it is understood as a right of needy people worldwide and is organized in the form of, for example, Pogge's concept of the Global Resource Dividend (GRD) (Pogge 2008), then it would be very difficult to abuse. In this paper, aid is understood in the latter sense. Besides, giving aid is just one of the duties and obligations of rich countries and these other duties and obligations should forestall the misuse of aid by its givers in this way.

Whereas generally the economics of "Trade not Aid" is based on valid arguments in relation to the sustainability of development of poor countries, aid may still be an inevitable obligation in global justice. In order to understand the inevitability of aid in efforts to achieve global justice, Miller's point about vulnerability mentioned above needs to be taken seriously. This is because it is a self-evident truth that even if all countries observed requirements of international justice, fair trade regimes and so forth, many people around the world would still remain below the material and social threshold needed for ensuring the level of well-being that is considered just. Local conditions - natural and those amenable to human efforts, market failures, technical and technological deficits etc. - would still render citizens of some countries socially and economically vulnerable, especially those in low-income countries. This fact leads to a moral requirement on those who have surplus resources to transfer some of these to those who are in need. To emphasize the importance of aid in global justice David Miller emphasizes that in order to determine the extent of global liabilities on nations and states, "we need the idea of a global minimum a set of basic human rights which must be protected for people everywhere regardless of circumstances" (2007: 266). Charles Jones too defends basic human rights as the "moral 
minimum" required for the implementation of global justice (1999: 50-84). All these imply the stringency of the obligation to give aid as a matter of right of the poor.

Conversely, however, Terry (2000), Easterly (2006), Collier (2008) and many others have been concerned with the effectiveness of aid in poor countries and are all highly skeptical. Their analyses indicate that, for aid to be effective, certain conditions must exist within poor countries; or to put it differently, for such aid to be effective, governments of poor countries ought to bear and fulfill some relevant obligations. This point serves to reemphasizes the main point of this paper; that is, the obligations of poor countries and discussions about them are important supplements to those of rich countries if the mission of global justice is to be achieved and be achieved justly. Hence, drawing on evidencebased skepticism about the effectiveness of aid in poor countries, the point of this argument is that when governments of poor countries receive aid they incur obligations pertaining to the effectiveness with which such aid is managed; and that failure to meet such obligations ought to attract all sanctions available against governments. But there also lingers a question regarding whether or not rich countries should withhold aid to poor countries should the governments of the latter fail to fulfill their obligations. We will come back to this question later.

\section{Obligation of Effective Management of Aid}

In conceiving the obligations of poor countries, one of the relevant (hypothetical) questions to ask is: "What if the aid they receive from affluent countries as a result of rich countries fulfilling their obligation to aid, never trickles down to its intended beneficiaries or is never converted into the desired well-being for ordinary citizens?" The implication here is that governments of poor countries are representatives or agents ${ }^{3}$ of their citizens who bear an obligation to deliver aid to the citizens who are the intended beneficiaries as effectively as possible. In other words, the right to aid resides in the citizens not their agents (governments). This implies that even if governments of poor countries fail when it comes to this obligation, this does not exempt the affluent countries from giving aid to those they owe it to - the ordinary poor citizens in poor countries. Instead, the failure of poor country governments to fulfill this obligation adds another duty to aidgivers: that is, to find other feasible channels through which to fulfill their obligations.

The obligation to effectively manage aid is important for both practical and moral reasons. From a practical point of view, this is necessary as a complement to that of rich countries giving aid. In other words, for aid to make any impact on the lives of the poor, the governments concerned must be able and willing to convert it into desired well-being. From a moral point of view, if governments of poor countries behave as economic 'black holes' by way of mismanaging aid resources, then this will impose an unjust magnitude of burden on those who bear the obligation to give aid. (This point will be given more emphasis in arguing for the next obligation below.) It is these two reasons that would justify sanctions against poor country governments that fail to meet this obligation.

But, again here, there is a lurking dilemma involved in imposing obligations on poor countries, particularly sanctions in the case of failure to meet their obligations. For exam- 
ple, Pogge raises the issue of autocracy in poor countries and complicity of the elite therein with representatives of affluent nations harming the interests of the citizens in poor countries. In other words, Pogge would rightly argue that "the poor countries that perpetrate harms such as aggression or may fail on any obligations are not the same as the poor countries that are the intended beneficiaries of global justice". The former refers to the governments (the elite and bureaucrats), while the latter are the ordinary citizens, and these two should not be treated as one entity in the conception and implementation of obligations of poor countries. This means that it would be an injustice for the citizens of poor countries to be made to suffer any sanctions arising from their governments' failure to fulfill their obligations. Therefore, in thinking about poor countries' obligations for international justice, the primary focus ought to be the governments of poor countries. This means that if there are any sanctions to be imposed on poor countries for failure to fulfill their obligations then care must be taken to limit the effects of such sanctions to governments and not the poor citizens.

\section{Contributory Negligence and the Duty of Due Diligence}

\section{The Principle of Contributory Negligence}

Contributory or comparative negligence is a juridical principle. It means carelessness or lack of vigilance on the part of the plaintiff which (carelessness) has contributed to, and is in whole or in part the cause of the injury or harm he [or she] complains of, as having been caused to him [or her] by the defendant's fault. Contributory negligence is one's failure to avoid getting hurt by the defendant or it is the fault of the claimant in the very occurrence of the accident (GLH 1982: 587). The principle implies that failure by a person to exercise reasonable care for the safety of either himself [or herself] or his [or her] property so that he [or she] becomes blameworthy in part or in whole as an author of his [or her] own harm does not impose liability on the defendant. Therefore, under the principle of contributory negligence, justice demands that before the potential obligation bearer (defendant) is assigned the duty to compensate the victim, it should be inquired into to establish whether there was anything the victim of harm could have been reasonably expected to do in order to avoid harm suffered or mitigate its severity. On this account, the potential victims of injustice are believed to have a duty to exercise due diligence or reasonable care in order to avoid or mitigate harm to themselves. The implication of this principle is that it would be an injustice to assign a hundred percent obligation to rectify the harm to the obligation bearer (defendant), although part of the harm can be attributed to the negligence of the victim.

The principle of contributory negligence, sometimes called comparative negligence, arises in debates about global justice out of the following hypothetical question: "Is there anything poor countries can do or avoid in their governance to reduce their suffering so that they require less or no aid at all?" If this question is answered in the affirmative, then there should be an obligation of poor countries to exercise reasonable care $e^{4}$ or due dili- 
gence; that is, given evidence of rampant contributory negligence in poor countries, the specific obligations of poor countries arising from the question posed above would be that governments in poor countries have a duty and obligation to ensure due diligence in managing the economies of these countries. The relevance of this obligation or duty in relation to poor countries is based on the assumption (to be proved below) that governments of poor countries display what would constitute avoidable negligence or recklessness in the management of their affairs.

It is important to note that a discussion of this principle and its arising duty takes into account the fact that factors that cause and worsen global injustice are both local and international or global in nature; these being both natural and those amenable to human efforts. Hence, the argument being advanced here is that irrespective of whether the causes of global injustice are local or international; natural or purely dependent of human efforts, the exercise of reasonable care by the poor countries in the management of their affairs can facilitate efforts to mitigate them, eventually leading to global justice.

\section{Extrapolating the Principle into Global Justice Debate}

Charles Jones accepts that the rich should have an enforceable obligation in implementing social justice. However, he argues that "[i]n addition, avoidable activities which make it less likely that poor countries can meet their own citizens rights-claims could be disallowed, thus enabling those states to fulfill their obligations with less positive aid from other states" (1999: 70). By arguing that certain activities be disallowed in developing countries, Jones implies that in poor countries there are activities which can be regarded as reckless or not prudent enough to the extent that they stand in the way of ensuring that their citizens enjoy material and social conditions comparable to those which global justice intends to achieve for them. But in addition to Jones' negative requirement of refraining from harmful activities, poor countries can also be required to take certain prudent positive steps (activities) with diligence, incumbent in their obligations in ensuring global justice. Both these positive and negative steps should be those that, if taken, would forestall most of the causes of global injustice, whether these be domestic or international; artificial or natural. This argument implies that governments who flout these obligations would henceforth be liable to corresponding sanctions. Therefore, the principle of contributory or comparative negligence and its arising duty of exercising due diligence can be legitimately extrapolated into the debates of global justice.

\section{Should Poor Countries Bear Duties of Due Diligence?}

Looking at the argument raised by Jones above through the lens of the principle of contributory negligence, the answer to the question above depends on whether there is evidence that governments in poor countries are not diligent (decent) enough by way of what might be called recklessness in their governance systems. Should this issue prove to be the case, then at least two negative outcomes would arise: the first one is that, even if obligations of rich countries are met, they would not achieve global justice; secondly, it 
would be an injustice to coerce citizens of the rich countries to transfer resources to governments of poor countries in what may seem like rewarding recklessness. In light of the above question, the quality of governance in poor countries seems to point directly to the need to emphasize their duty to ensure due diligence.

To begin with, O'Neill raises the issue of population explosion in poor countries and argues that this worsens their already dire situation (O'Neill 1986: 158). O'Neill's claim is corroborated by population growth statistics in poor countries, which show that globally the highest population growth rates are recorded in poor countries. For example, according to population growth statistics for 2011, Uganda has the fifth highest population growth rate globally at $3.2 \%$ per annum, after the United Arab Emirates (UAE) (4.9\%); Bahrain (4.8\%); Zambia (4.2\%) and Niger (3.5\%) (World Bank 2013). Elsewhere, Uganda is ranked third globally with an annual population growth rate of $3.576 \%$ after Zimbabwe (4.31\%) and Niger (3.643\%). Generally, African countries which are most burdened by poverty and disease top population growth rate rankings (NationMaster 2013). O'Neill's argument is based on the assumption that population explosion has a negative impact on the socio-economic well-being of people (in terms of income, savings, health etc.). If this assumption is correct then in order to improve socio-economic conditions in poor countries (such as household savings and health conditions) poor countries should bear the obligation of reducing their population growth rates.

However, the argument about population control as presented by O'Neill above can arguably suffer from two potential doubts: One is that it appears to put the cart before the horse. This is because in some cases population growth seems to be dependent on economic and social development and therefore very difficult to control in itself; that is, low birth-rates being regarded as a consequence of improved socio-economic conditions especially health care and education. However, at the same time it is possible that low population growth rates are a precondition for improvement in standards of living. It is plausible to argue that a poor country that prioritizes population control in its resource allocation and public policy will quickly reduce both government and household expenditures and at the same time reduce pressure on the limited social services. The second potential problem may arise from the legitimacy of authoritarian and corrupt governments in poor countries to enforce population control. But since such enforcement would be in the best interest of the citizens, then this could be allowed for and count as at least one credit to such governments.

Further, some of the practices in poor countries, especially those pertaining to governance, justify the imposition of the duty to exercise due diligence. Drawing from the general criticism against aid raised by Terry, Easterly and Collier among others as pointed out above, the factors which undermine the effectiveness of aid can be exemplified in specific countries. These factors count as failure to exercise due diligence among poor countries. For example, Uganda which relies heavily on the Global Fund and other external aid sources for the health sector has several times been implicated in what can count as negligence. This is evidenced by very high levels of corruption with impunity. In this case, high levels of corruption with impunity constitutes clear failure of the principle of due diligence on the part of government. There are some particular popular cases that con- 
firm this failure: In 2007 it was discovered that "[a]s thousands of Ugandans die every day of HIV/Aids and malaria, drugs worth about UGX 4 billion [around \$1.6 million USD] are rotting [have expired] in the National Medical Stores Entebbe" (Nandutu 2007). It was also revealed that "[s]tolen government drugs [are] repackaged and resold to National Medical Stores" (Ayebazibwe 2012). Other poor countries have been found guilty too and they have also been either asked to refund the Global Fund money or forfeit subsequent rounds of funding. These include Pakistan, Ukraine, Myanmar, Senegal, Chad, Nigeria, Kenya, Zimbabwe, Namibia, and Togo, to mention but a few (IRIN 2009).

To further illustrate the point, one can look at a sample of Uganda's "Nine Corruption Scandals to Look Back at" (New Vision, 2014). According to this research, in only nine corruption cases, at least $\$ 0.42$ billion USD was lost in the hands of different public officials; the majority of these were politically exempt from liability resulting in no hope of recovering the money. Generally, according to the results of the Corruption Perception Index (CPI) for countries over the years, there is a high correlation between being a corrupt country and being a poor country. Even if it is arguable whether corruption at a national level is a cause or an effect of poverty, it seems to make better sense to argue that corruption is an obstacle to social, economic and political development and it takes political will to successfully fight corruption.

In light of these and potentially more pieces of evidence, the principle of contributory negligence points to the need for poor countries to bear a moral obligation to exercise due diligence in managing their affairs. The pragmatic value of this obligation is that it would make concerned obligation bearers more vigilant and prudent in managing their affairs. This will in turn reduce their chances of being harmed by other agents' behaviors or natural factors. Furthermore, from a moral point of view it would be an injustice to ask other obligation bearers, particularly citizens of rich countries, to incur costs which are a result of avoidable omissions and commissions on the part of governments of poor countries, if there are no efforts to hold perpetrators accountable. By and large, ignoring the principle of contributory negligence and its arising duty to exercise due diligence in global justice debate would lead to complacence, and more recklessness on the part of the governments of poor countries, making it more difficult to achieve global injustice. Therefore, poor countries ought to bear an obligation/duty to exercise due diligence in order to mitigate the level of injustice they suffer and also reduce the liability of other agents.

\section{Some Potentially Persistent Challenges}

The question of obligations of poor countries in global justice is quite complex and this paper does not claim to provide an exhaustive and uncontroversial account of them. But certainly from the above discussion it has transpired that there is a need to mainstream a discussion of these obligations into debates about obligations of global justice. In this effort, however, challenges lurk that need critical attention. Most of the challenges will potentially arise in the implementation of these obligations. One of these is how to hold governments of poor countries accountable should they flout these obligations, without 
harming the interests of their needy citizens. We have treated governments and citizens of poor countries as two different entities as most of these governments lack legitimacy in the sense of not being truly representative of the interests of their citizens. Hence, since obligations of poor countries need to be enforceable in order to be effective, the mode of their enforcement ought to draw a clear line between the obligation bearer (governments) and the intended beneficiaries of global justice. This in turn implies that even if poor country governments flout their obligations, rich countries retain their obligations to the citizens of poor countries.

From the above, another challenge in the conception and enforcement of obligations of poor countries arises in the case of their governments failing to fulfill their obligations: that is, how can the rich countries fulfill their obligations to the global poor without doing so through the agency of their governments? Could this be done through Civil Society Organizations (CSOs)? However, whereas the community of civil society would promise an effective channel, the successful operation of civil society in any country still to a great extent depends on the smooth relations between the two. But since some CSOs (such as the UN and Red Cross) have immunity against government interference, it would be possible to bypass potential sabotage from uncooperative governments.

One may well wonder: How can one assign obligations to countries like Uganda that do not fulfill any, or at least most, of the requirements of good governance? Would it not be a waste of time? Yes, it may appear so, especially if there are no means to enforce such obligations internationally. But since obligations of justice are (here) meant to be enforceable and all obligations of poor countries argued for above point to the requirements of good governance, assigning governments of poor countries related obligations seems not to be in vain.

Finally, from our arguments above, the ordinary citizens of poor countries seem to be completely exempt from bearing any obligations. This exemption is also potentially controversial. From the point of view of the importance of human agency, it can be interpreted as an assault on the autonomy of citizens in poor countries. It is therefore a worthwhile exercise to consider the possibility of such obligations (for citizens). These obligations might relate, for example, to their vigilance and support for the civil society and their compliance with the positive and negative prescriptions to them relating to actions that are aimed at improving their conditions, hence making it easier for them to approach the material threshold which global justice aims at. But since the performance of individual citizens depends on the effectiveness of public institutions, it is proper to prioritize a discussion of obligations of their governments. All these issues (and probably more) are unsettled questions in the conception and implementation of obligations of poor countries in ensuring global justice; however, they cannot be sufficiently adjudicated in the limited space of this paper. Accordingly these challenges need to be born in mind in the discussions of obligations of poor countries in global justice. 


\section{Conclusion}

The obligations of poor countries are crucial for the achievement of global justice, yet these obligations are largely side-stepped in current discussion. At best, as is the case with many authors, these obligations are simply alluded to and this can reduce their stringency. In the first place, by engaging in aggression against other states, poor countries deprive their victims' material livelihoods and social well-being - both of which have serious ramifications on a global justice scale. Secondly, although not the most important condition for the development of poor countries, obligation to aid is crucial in global justice, yet experience shows that its effectiveness is not guaranteed due to moral weaknesses in poor country governments. For this reason, when governments of poor countries receive aid, they ought to incur stringent obligations to effectively manage such resources to the benefit of its intended beneficiaries. Thirdly, given the available evidence about the poor quality of governance in most poor countries it has been shown that poor countries are morally liable to bear the duty of exercising due diligence in the management of their affairs. Finally, it is important to emphasize the point that, the discussion in this paper does not constitute a denial of the importance of the obligations of rich countries; rather it is an emphasis of the additional obligations of the governments of poor countries. If we emphasize the obligations of the governments of rich countries and neglect those of poor countries, it will not be possible for the citizens in poor countries to benefit from the efforts of rich countries and it will engender injustice against citizens of affluent countries.

\section{Notes}

${ }^{1}$ Rich countries too, may, or actually do, engage in armed aggression, but the concern of this paper is the obligations of poor countries.

${ }^{2}$ By harmful victims, we mean victims of global injustice (poor countries), but whose domestic and international behavior is harmful to their citizens and other countries, as we illustrate using the case of Uganda. This creates a dilemma as to whether such harmful victims deserve positive actions such as aid from the affluent countries.

${ }^{3}$ By saying that governments of poor countries act as agents of their citizens, we are not committed to saying that such governments are representative in a truly democratic sense. Rather, we mean that whatever such governments receive or do is all purportedly done in the name of their citizens.

${ }^{4}$ According to Gerald N. Hill and Kathleen T. Hill (1981-2005), 'Reasonable Care' refers to the degree of caution and concern for the safety of oneself and others that an ordinarily prudent and rational person would apply in the circumstances.

\section{Literature}

Armed Activities on the Territory of the Congo (Democratic Republic of the Congo V. Uganda), Judgment, I.C.J. Reports 2005, p. 168.

Ayebazibwe, A. (2012) Stolen government drugs repackaged and resold to National Medical Stores, The Daily Monitor, $3^{\text {rd }}$ Nov. 
Barsdorf, N. W. (2012) South Africa's Duty to Support Health Research for the Global Poor. PhD diss., University of Bergen, Norway.

Choudhari Fuljibhai v. Fakirmohaned [1982] GLH 578. Contributory and Composite Negligence.

Collier, P. (2008) The Bottom Billion: Why are poor countries failing and what can be done about it. Oxford: Oxford University Press.

Easterly, W. (2006) The white man's burden: Why the West's efforts to aid the rest have done so much ill and so little good. New York: The Penguin Press.

Golding, M. P. (1975) Philosophy of Law. Englewood: Cliffs, New Jersey: Prentice-Hall.

Hart, H. L. A. (1979) Between Utility and Rights. In: The Idea of freedom, ed. R. Alan, pp. 828-846. Oxford: Oxford University Press.

Hill, G. \& Hill, K. (1981-2005). Legal Dictionary. Retrieved from http://dictionary.law.com/ Default.aspx?review=true

IRIN (2009) Global: Falling foul of the fund. Retrieved from http://www.irinnews.org/ Report81295/GLOBAL-Falling-foul-of-the-Fund

Jones, C. (1999) Global Justice: Defending cosmopolitanism. Oxford: Oxford University Press.

Nagel, T. (2005) The Problem of Global Justice. Philosophy and Public Affairs, 33, (2), pp. 113-147.

Nandutu, A. (2007) Shs3.7 Billion Malaria, ARV Drugs Rot in National Medical Stores. The New Vision, $7^{\text {th }}$ Jul.

NationMaster (2013) People Statistics > Population growth rate (most recent) by country. Retrieved from http://www.nationmaster.com/graph/peo_pop_pro_rat-people-populationgrowth-rate

Nine corruption scandals to look back at (2012). New Vision: Uganda's Leading Daily, $5^{\text {th }}$ Aug. http://www.newvision.co.ug/news/637209-nine-corruption-scandals-to-look-back-at.html

O’Neill, O. (1986) Faces of Hunger: An essay on Poverty, Justice and Development. London: Allen and Unwin.

O’Neill, O. (1996) Towards Justice and Virtue: A Constructive Account of Practical Reasoning. London: Cambridge University Press.

Pogge, T. (2001) Priorities of Global Justice. In: Global Justice, ed. T. Pogge, pp. 6-24. Oxford: Blackwell.

Pogge, T. (2005) Human Rights and Human Responsibilities. In: Global Responsibilities, ed. A. Kuper, A., pp. 3-36. New York and London: Routledge.

Pogge, T. (2008) World Poverty and Human Rights ( $2^{\text {nd }}$ Ed.). Malden, USA: Polity Press.

Scheid, D. E. (2012) Aggression: Humanities, Social Sciences and Law: The Encyclopedia of Global Justice. Retrieved from http://www.springerreference.com/docs/html/chapterdbid/ 328 008.html

Shue, H. (1996) Basic Rights: Subsistence, Affluence and U.S. Foreign Policy. Princeton NJ: Princeton University Press.

Shue, H. (2006) Basic Rights. In: Contemporary Political Philosophy: An Anthology (2 ${ }^{\text {nd }}$ Ed.), ed. R. E. Goodin \& P. Pettit, pp. 302-316. Australia: Blackwell Publishing.

Singer, P. (2000) One World: The Ethics of Globalization. New Haven, CT: Yale University Press.

Terry, F. (2000) Condemned to Repeat? The paradox of humanitarian action. Cornell Press, New York.

The World Bank Group (2013) Democratic Republic of Congo. from http://www.worldbank.org/ en/country/drc

The World Bank (2013) Population Growth (annual \%). Retrieved from http://data.worldbank.org/indicator/SP.POP.GROW 